\title{
Pleieren er den beste medisinen
}

I demensboligen Haugsåsen har beroligende tabletter blitt erstattet med økt kunnskap om uro, tilstedeværende pleiere og et miljø pasientene kjenner seg igjen $\mathrm{i}$.

\section{Forfatter}

\section{Caroline Boda Sakariassen}

Fagsykepleier

Haugsåsen bokollektiv, Skien kommune

\section{Nøkkelord}

Demens Psykofarmaka Miljøterapi

Sykepleien 2018 106(65757)(e-65757)

DOI: https://doi.org/10.4220/Sykepleiens.2018.65757

\section{HOVEDBUDSKAP}

Haugsåsen bokollektiv jobber med å redusedre bruken av psykofarmaka ved å bedre kunnskapen og holdningene til personalet, øke forståelsen for polyfarmasi samt informere pårørende. Samtidig fokuserte de mer på hverdagslig miljøterapi. Personalet erfarte at det er lettere å nå inn til beboerne når de ikke bruker psykofarmaka.

Bruk av psykofarmaka hos mennesker med demens er utbredt. Årsakene er mange og komplekse (1, 2). På Haugsåsen bokollektiv i Skien hadde vi et høyt forbruk av slike medikamenter. I tillegg opplevde vi at flere beboere hadde høy falltendens, større søvnbehov, nedsatt ernæringstilstand og økende uro og forvirring. 
Ved å redusere og seponere psykofarmaka opplevde vi at uroen var den samme, men bivirkningene ble redusert. Appetitten økte, falltendensen avtok, og vi så at flere ble mer våkne. Samtidig fokuserte vi mer på hverdagslig miljøterapi og innførte små tiltak som appellerte til den enkelte beboerens identitet og mestringsfølelse.

LES: Her får ingen demenspasienter beroligende $\underline{\text { legemidler }}$

Med miljøterapi eller miljøbehandling hos oss mener vi at vi bruker oss selv og våre fysiske rammer for å oppnå lindring eller behandling av uro. Ved å være sammen med og samhandle med beboeren forsøker vi å se beboeren og være der gjennom vonde følelser, angst og forvirring, og på den måten lette beboerens lidelse (3).

\section{三 «Appetitten økte, falltendensen avtok, og vi så at flere ble mer våkne.»}

Miljøterapi trenger ikke omfatte store aktiviteter som inkluderer alle beboerne på en avdeling. Individuelt tilpassede tiltak gjør at beboeren føler seg hørt og inkludert. Hos oss vet vi at vi ikke alltid klarer å skape gode hverdager, men vi vektlegger å skape gode øyeblikk.

\section{Høyt forbruk}

Da vi deltok i pasientsikkerhetsprogrammet Riktig legemiddelbruk på sykehjem, ble en tanke sådd når det gjaldt bruken av medikamenter hos eldre med demens. Legen og sykepleierne fikk i oppgave å dra tilbake på jobb og se over medikamentbruken - spesielt beroligende medikamenter. 
Det vi oppdaget, var at vi hadde et høyt forbruk av beroligende, men likevel var beboerne fortsatt urolige. Vi kartla beboere som fikk beroligende, og noterte hvor mye de fikk. Vi ønsket å kartlegge medikamentbruken på nytt etter at vi var ferdige med pasientsikkerhetsprogrammet. Samtidig tenkte vi at vi måtte gjøre noe med det fysiske miljøet.

\section{三 «Vi hadde et høyt forbruk av beroligende, men likevel var beboerne fortsatt urolige.»}

Vi vet at mange mennesker med demens har tidsforskyvninger og ikke er mentalt til stede i nåtida. Stua på den ene avdelingen minnet om et venterom, ikke bare for oss, men også for beboerne. De satt i stolene, kikket på klokkene sine og lurte stadig på når bussen, toget eller legen kom.

Psykiatrien har som mål at både pleierne og de fysiske rammene, altså oppholdslokalene, skal skape trygghet og mestringsfølelse. Denne tanken ville vi overføre til hvordan vi jobber hos oss.

\section{Underviste internt}

Vi som pleiere har forskjellige oppfatninger av hva uro er, uansett om vi er fagutdannet, høyskoleutdannet eller assistent. Som mennesker preges vi av beboernes uro på forskjellige måter; noen har lavere toleransegrense for uro enn andre.

Vi ønsket at pleierne skulle få mer kunnskap om og forståelse av at uro kan være et symptom. Uroen kan være et uttrykk for normal demensatferd, men også for et behov eller en somatisk sykdom. Derfor underviste vi cirka 50 ansatte internt om hva demens og uro er. 
I internundervisningen forklarte vi hva symptomene på demens er - uro, forvirring, angst og utageringer - og at disse symptomene er normal demensatferd. I tillegg gikk vi inn på begreper som validering, reminisens og livshistorie. Validering innebærer å anerkjenne følelsene til beboeren, for eksempel bekrefte at det er greit å være redd, engstelig og trist. Ved reminisens eller ved å gjenkalle minner henter vi frem noe som skaper gode følelser.

Når vi legger til rette for at brukeren kan kjenne igjen noe, enten en gjenstand eller en følelse, gjør vi det mulig for personen med demens å bidra med noe, enten kunnskap eller et minne (4).

Ved å innhente livshistoriene til beboerne får vi innsikt i hvem de er og har vært som personer. Vi får informasjon om deres yrkesliv og familie. Vi skaper en inngangsport til reminisens. Beboerne får anledning til å snakke om kjente ting som skaper mestringsfølelse.

Vi appellerer til deres identitet - at de skal bli sett, hørt og inkludert.

\section{Startet nedtrapping}

Da vi sammen med legen startet en nedtrapping av beroligende medisiner, opplevde vi en økende uro hos noen av beboerne. Pleierne på avdelingen ble frustrerte og ville at vi skulle gi dem tilbake de beroligende medisinene. Legen kunne forklare at det mest sannsynlig var snakk om abstinenser som skapte uroen, men at det ville gå over. Vi måtte bare stå i det.

Vi erfarte også at når de beroligende medikamentene var helt seponert, roet noen beboere seg. Andre hadde samme uro som da vedkommende fikk beroligende. Det som er viktig for oss, er at beboerne skal ha den medikamentelle behandlingen som er nødvendig, men de skal ikke ha medikamenter som ikke er nødvendige, og som gir uheldige bivirkninger. 
Mennesker med en demensdiagnose har mange

bekymringer. Bekymringer for økonomien, for at barna er hjemme alene, for at de har gamle og syke foreldre de må ivareta, for at de ikke finner frem i miljøet, og for at de ikke vet hvor toalettet er. Som helsepersonell må vi forstå at et slikt symptom ikke kan behandles bort, men vi kan i stor grad forsøke å redusere uroen.

\section{Diagnose og behandling}

Når man jobber med mennesker med demens, må man lære seg og erfare at symptomer som forvirring, angst og utageringer i stor grad ikke kan behandles. Demens er en progredierende sykdom som man dør med eller av, og symptomene den gir, er i stadig forandring.

Sykepleierne må ha samme kunnskap og erfaring som andre som jobber med denne pasientgruppen. Vi har derfor lagt vekt på lik internopplæring til sykepleierne og resten av personalet. Hensikten er at alle skal ha en lik forståelse av demensatferd. Som sykepleier er vi utdannet til å stille sykepleierdiagnoser, og deretter finne en løsning. Vi tenker diagnose og behandling.

Sykepleierne har deretter fokusert på farmakodynamikk og farmakokinetikk - altså hva medisiner gjør med kroppen, og hva kroppen gjør med medisiner. Når man jobber med eldre, er det viktig å ha kunnskap om hvordan aldring og sykdom forandrer måten kroppen tar opp medisiner på. Det er avgjørende å vite om virkninger og bivirkninger av ulike medikamenter.

\section{Hvordan håndtere uroen?}

I tillegg må man kartlegge uroen: Er den somatisk betinget, må den utredes og behandles dersom det er nødvendig. Er uroen psykisk betinget, må man undersøke, observere og kartlegge hva som kan trigge uroen. 


\section{三 «Vi er opptatt av at de som bor her, skal få det de trenger av medisiner, men ikke mer.»}

Da vi seponerte beroligende, var beboerne like urolige som da de fikk beroligende. Fordelen er at de slipper bivirkningene, som eldre er mer utsatt for å få. Økt falltendens, mer forvirring og uro, nedsatt matlyst. Vi er opptatt av at de som bor her, skal få det de trenger av medisiner, men ikke mer.

Ved å bruke validering, reminisens og livshistorie kan man avlede eller «behandle» uroen. I de fleste tilfellene går uroen naturlig over av seg selv. Dersom man skal gi beroligende enten fast eller ved behov, må man vite at det kan ta opp mot to til fire timer før en slik tablett virker på eldre. Etter så lang tid har uroen i mange tilfeller gått over av seg selv, og brukeren sitter igjen med bivirkninger.

Pleieren er den beste medisinen for en person med demens. Vi mener at det å møte et menneske med anerkjennelse, bekreftelse, støtte og trøstende ord har mer effekt enn en beroligende.

\section{Beroligende vs. miljøterapi}

På arbeidsplassen vår har vi mange flinke ansatte som gjør sitt ytterste for beboerne hver eneste dag. Vi står i tunge stell, i vanskelige tilfeller med pårørende og beboere. Vi rir av stormen ved utfordrende atferd, forvirringstilstander, uro, vandring og angst. Vi har ingen enkel jobb; den krever mye av oss, både som mennesker og fagpersoner. Vi blir slitne og lei.

For noen er det en redning å kunne gi en beroligende tablett til en beboer som har vandret hele dagen, for da blir vedkommende endelig rolig. Vi har ofte stilt oss spørsmålet om vi endrer atferden vår overfor beboeren når vi gir dem beroligende. Har den beroligende pillen en effekt på oss? 
Etter å ha jobbet i mange år med mennesker med demens, vet vi at atferden vår smitter over på beboerne. Kommer vi på jobb og er stresset, prater mye, rydder, bråker og farter frem og tilbake, skaper vi uro.

Det er viktig å bruke tid på å anerkjenne personalets følelser og skape rom for å uttrykke frustrasjon og følelse av hjelpeløshet. Gi rom for at man en dag kan være på en annen avdeling for å få litt pusterom eller miljøskifte.

Som sykepleiere har vi et ansvar for at beboerne får best mulig helsetilbud, omsorg og pleie. Ved å ivareta personalet på en slik måte ivaretar vi også beboerne. Vi må ha tålmodighet når vi håndterer uro. Dagene er ikke like. Noen dager er uroen større enn andre dager.

\section{Gitar og håndarbeid}

Begrepet «miljøterapi» brukes løst og fast, og det finnes mange definisjoner på hva ordet betyr, og hva det skal inneholde. Mange vil ikke høre om miljøterapi, for ordet skaper forventninger. Forventninger til meg som ansatt om hva jeg skal prestere.

Selv kan jeg verken spille gitar eller piano, eller synge. Hos oss legger vi lista lavt når det gjelder miljøterapi. Vi kan ikke samle sju beboere i en ring og spille gitar og forvente at alle skal synes det er like stas. Noen blir overstimulert, og det skaper uro. Noen sovner, mens andre synes det er veldig hyggelig. Det er her det er viktig å kjenne sitt publikum.

Hos oss er det lov å ta med håndarbeid på jobb. Vi damer viser mønstre og farger og snakker om hvor mye vi har strikket tidligere, mens mennene husker at konene deres strikket, eller at moren strikket gensere til dem. Strikking er en rolig aktivitet som skaper et felles samtaleemne og en følelse av tilhørighet.

\section{Skaper mestringsfølelse}


Om sommeren griller vi pølser, deler en kald lettøl i sola og bowler på gresset. Noen kler av seg og sitter i bar overkropp eller i bh-en og soler seg - slik de gjorde da de bodde hjemme. Vi går en tur rundt bygget eller i sansehagen. Leser dikt, hører på musikk, limer inn bilder i album. For oss er dette miljøterapi.

\section{三 «Hos oss vektlegger vi hverdagslige aktiviteter som miljøterapi.»}

Noen vil nok si at miljøterapi skal være en systematisk og gjennomtenkt aktivitet, men hos oss vektlegger vi hverdagslige aktiviteter som miljøterapi. Mennesker med demens trenger å kjenne på en mestringsfølelse, og ved å gjennomføre hverdagslige aktiviteter som de husker, skaper vi nettopp en slik følelse.

\section{Som å være detektiv}

Sykepleierens rolle er, sammen med personalet, å være en pådriver for veiledning, kartlegging og forklaring. Vi skal gå foran som et godt eksempel. Vi må være faglig sterke nok til å svare på spørsmål fra og diskutere med både kollegaer og pårørende. Fagkunnskap og erfaringskompetanse spiller en avgjørende rolle for å kunne stå i denne typen arbeid.

Det er mange årsaker til at nye beboere kommer inn med lange medisinlister og høyt forbruk av beroligende. Som sykepleier på sykehjem eller bokollektiv har vi da ansvar for, sammen med lege og andre kollegaer, å kartlegge behovet for medikamentell behandling. Noen har kanskje fått beroligende medisiner av fastlegen da de var mye alene som hjemmeboende med hjemmesykepleie. 
Å være sykepleier og jobbe med geriatriske pasienter er som å være detektiv. Man må lete etter årsaker til hvorfor pasienten er mer urolig eller forvirret enn tidligere. Det er viktig å vite at en person ikke bli mer dement over natten. Ofte er det en akutt eller subakutt sykdom som bidrar til endringen. Da må man begynne å lete systematisk etter årsaken til den akutte forvirringen.

\section{Referanser}

1. Wyller TB. Eldre og legemidler. I: Bondevik M, Nygaard HA, red. Tverrfaglig geriatri. En innføring. Bergen: Fagbokforlaget; 2012. s. 131-40.

2. Ulstein I. Demens. I: Bondevik M, Nygaard HA, red. Tverrfaglig geriatri. En innføring. Bergen: Fagbokforlaget; 2012. s. 295-303.

3. Lillevik OG, Øien L. Hva er miljøterapi? Sykepleien. 2015;103(5):60-3. Tilgjengelig fra: https://sykepleien.no/forskning/2015/04/hva-ermiljoterapi (nedlastet 19.02.2018).

4. Balteskard B, Storli SL, Martinsen K. Hendene husker ullas uttrykk - om betydningen av å gjøre tilværelsen rommelig for pasienter på sykehjem. Nordisk sygeplejeforskning. 2012;2(3):167-79. 